\title{
Hubungan Antara Konsep Diri Dengan Prestasi Akademik Mahasiswa Pada Mata Kuliah Teori Grup
}

\section{Hanifah' dan Agung Prasetyo Abadi²}

\author{
1,2Program Studi Pendidikan Matematika FKIP Universitas Singaperbangsa Karawang \\ Corresponding Author: hanifah@fkip.unsika.ac.id'
}

DOI: http://dx.doi.org/10.15294/kreano.v10i2.19369

Received: May 23 2019; Accepted: December 2 2019; Published: December 42019

\begin{abstract}
Abstrak
Tujuan penelitian ini adalah untuk mendeskripsikan hubungan antara konsep diri dengan prestasi akademik mahasiswa pada mata kuliah teori grup. Penelitian ini merupakan penelitian campuran dengan deskriptif kualitatif. Subjek dalam penelitian ini adalah mahasiswa semester IV kelas E Program Studi pendidikan Matematika FKIP UNSIKA. Instrumen yang digunakan dalam penelitian ini berupa angket konsep diri dan hasil akademik mahasiswa. Dari hasil analisis korelasi sederhana, diperoleh nilai koefisien korelasi antara konsep diri dengan prestasi akademik mahasiswa sebesar 0,41. Berdasarkan perolahan data diperoleh kesimpulan bahwa terdapat hubungan yang positif dan signifikan antara konsep diri dengan prestasi akademik mahasiswa pada mata kuliah teori grup.
\end{abstract}

\begin{abstract}
The purpose of this research was to describe the corelation betwen self-concept with academic achievement college student in teori grup courses. This research was mix-method with descriptive qualitative. The subject of this research was college student of Fourth Semester on E Class in Educational Faculty of Singaperbangsa University. The instrument of research was some self-concept questionnaire and academic achievement college student score. The result of simple corelation analysis was 0,41. Based on the data, it concluses that there was positive and significant corelation between self-concept and academic achievement college student in teori grup courses.
\end{abstract}

Keywords: self-concept, academic achievement, teori grup

\section{PENDAHULUAN}

Matematika sebagai salah satu mata pelajaran dasar pada setiap jenjang pendidikan formal yang memegang peran penting. Matematika merupakan alat yang dapat memperjelas dan menyederhanakan suatu keadaan atau situasi melalui abstrak, idealisasi atau generalisasi untuk menjadi suatu studi ataupun pemecahan masalah.

Dalam pelaksanaan pembelajaran di sekolah usaha untuk meningkatkan hasil belajar siswa banyak mengalami kendala dan hambatan. Lebih-lebih pada pelajaran matematika yang menuntut begitu banyak pencapaian konsep sehingga mengakibatkan hasil belajar kurang memuaskan. Saat ini, masih cukup ba- nyak Siswa yang merasa kesulitan dalam belajar matematika. Hal ini disebabkan karena anggapan bahwa matematika sulit. Dengan anggapan itu akhirnya berpengaruh terhadap hasil belajar siswa (Purnamasari, 2017).

Rosmaiyadi (2018) menyatakan bahwa matematika bukan sekedar ilmu hitung menghitung, tetapi juga dapat digunakan untuk membuktikan kebenaran ide dan memecahkan masalah melalui cara berpikir yang logis dan terstruktur. Seperti halnya isi materi pada mata kuliah teori grup yang berupa teori-teori dasar dan pembuktian teorema, serta sedikit aspek perhitungannya. Hal ini sejalan dengan pendapat Listiawati (2015) yang menyatakan bahwa aljabar abstrak adalah mata 
kuliah yang mempelajari struktur aljabar, seperti grup dan ring. Objek-objek dalam aljabar abstrak beragam dan tidak hanya menyangkut objek-objek matematika yang telah lazim dikenal seperti: bilangan, bilangan bulat modulo, matriks, dan fungsi. Akibatnya objek dalam aljabar abstrak seolah-olah lebih abstrak dibandingkan dengan objek matematika pada umumnya. Slamet (2004) mengatakan bahwa Aljabar masih menakutkan bagi mahasiswa. Penelitiannya menyimpulkan bahwa penguasaan operasi dasar matematika sebagai bekal memanipulasi bentuk-bentuk aljabar marupakan persoalan yang serius bagi mahasiswa. Ada tiga faktor penyebab kegagalan pengajaran Aljabar di perguruan tinggi yakni mahasiswa, dosen dan bahan ajar. Khusus dari faktor mahasiswa dikatakan "Kemampuan mahasiswa dalam aljabar sangat berkaitan dengan bekal mahasiswa ketika belajar dijenjang sebelumnya. Dengan demikian, dalam mempelajari hubungan antar objek dalam aljabar abstrak memerlukan penalaran yang sangat kuat. Penekanan pada teori dasar, pembuktian, dan sedikit perhitungan ini menyebabkan mahasiswa senantiasa mengalami kesulitan dalam memahami materi mata kuliah teori grup. Mahasiswa terbiasa dengan perhitungan matematika, tidak terbiasa dengan proses pembuktian matematika. Salah satu cara yang dapat dilakukan untuk dapat memahami materi pada mata kuliah teori grup yaitu mahasiswa harus mempunyai keterampilan mengerjakan soal matematika yang sangat sesuai diperlukan dalam mempelajari bidang studi lain. Berdasarkan hal tersebut, matematika dianggap sebagai ilmu yang sangat penting dan diajarkan hampir di semua jenjang pendidikan, mulai dari sekolah dasar, sekolah menengah hingga perguruan tinggi.

Menurut Astuti (2010), perguruan tinggi sebagai lembaga pendidikan tinggi dalam proses belajar mengajarnya dikenal dengan istilah perkuliahan. Tantangan utama yang dihadapi setiap lembaga pendidikan adalah bagaimana dan apa yang harus dilakukan sehingga lulusannya mampu merealisasikan tujuan dan cita-cita dari lembaga tersebut. Tantangan tersebut dapat dirumuskan dengan lebih sederhana, yaitu pengalaman apa yang harus diberikan kepada mahasiswa selama pendidikannya, sehingga profil atau kompetensinya dapat berkembang dari profil atau kompetensi sebagai mahasiswa baru, yaitu Iuluan SMA, menjadi sarjana pendidikan matematika yang dicitacitakan. Untuk menentukan bagaimana pengalaman itu harus dihadapkan pada mahasiswa, pengenalan atas profil mahasiswa baru sangat penting untuk diperhatikan. Karena pengalaman yang dihadapkan dengan cara yang tidak sesuai, dapat memberikan dampak yang tidak sesuai dengan harapan, bahkan dapat berlawanan dengan yang diinginkan. Yang penting dikenali dalam profil mahasiswa baru, disamping kualitas dan kuantitas penguasaan matematikanya, penting pula dikenali dengan baik sikap terhadap matematika. Suatu lonjakan yang cukup tinggi antara pengetahuan di SMA dan materi yang diajarkan di tahun awal akan dirasa sangat menyukarkan mahasiswa dan ini dapat menumbuhkan ketidaksenangan atas pelajaran terkait dan selanjutnya akan mengakibatkan kegagalan.

Kegagalan dan keberhasilan mahasiswa dalam mencapai prestasi belajar juga dipengaruhi oleh konsep diri. Konsep diri menjadi hal penting bagi tercapainya prestasi belajar karena konsep diri termasuk dalam faktor internal yang mempengaruhi siswa dalam pencapaian prestasi. Penelitian Rensi dan Sugiarti (2011) menyatakan bahwa siswa yang memiliki prestasi tinggi memiliki konsep diri yang lebih positif, sedangkan siswa yang memiliki prestasi rendah memiliki konsep diri yang negatif. Siswa yang kurang berprestasi akan memandang diri mereka sebagai orang yang tidak memiliki kemampuan dan kurang mampu beradaptasi dengan orang lain. Tanggapan positif guru juga dapat membantu siswa bersikap positif terhadap dirinya dan juga dapat mempengaruhi prestasi belajarnya.

Shavelson, Hubner, dan Stanton (1976) menyatakan bahwa konsep diri adalah persepsi seseorang terhadap dirinya sendiri yang dibentuk melalui pengalaman dan interpretasi seseorang terhadap dirinya sendiri. Burns (1979) mengatakan konsep diri sebagai pandangan, penilaian, dan perasaan individu mengenai dirinya yang muncul sebagai hasil dari suatu interaksi sosial. Crocker dan Wolfe 
(2001) mengatakan bahwa konsep diri adalah pandangan seseorang mengenai dirinya secara keseluruhan sebagai hasil pengamatan terhadap dirinya di masa lalu dan di masa sekarang. Penelitian Rensi dan Sugiarti (2011) menunjukkan bahwa adanya hubungan antara konsep diri dengan prestasi belajar siswa SMP Kristen YSKI Semarang dengan koefisien regresi sebesar 0,158. Penelitian Irawati dan Hajat (2012) menemukan bahwa self esteem yang merupakan faktor internal konsep diri dapat mempengaruhi prestasi belajar. Selain itu juga terdapat penelitian dari Handayani dan Nurwidawati (2013) adanya hubungan antara konsep diri dengan prestasi belajar siswa akselerasi dengan koefisien korelasi sebesar 0,657 . Penelitian dari Vandini (2016) dan Ameliah (2016) menunjukkan bahwa faktor psikologis, yaitu rasa percaya diri juga dapat mempengaruhi prestasi belajar. Hubungan positif dan signifikan antara rasa percaya diri dengan prestasi belajar siswa juga ditunjukkan dalam penelitian-penelitian lain yang serupa (Achdiyat dan Lestari, 2016; Tisngati dan Meifiani, 2014)

Namun, penelitian Firmanto (2010) menunjukkan bahwa terdapat hubungan yang lemah dan tidak signifikan antara konsep diri dengan prestasi belajar siswa SMA Shalahuddin Malang. Penelitian yang dilakukan oleh Prasetyo (2013) juga menunjukkan bahwa konsep diri tidak memiliki pengaruh yang signifikan terhadap prestasi belajar siswa kelas XI dan XII Jurusan Teknik Audio Video SMK Muhammadiyah 3 Yogyakarta.

Berdasarkan uraian di atas, maka rumusan masalah yang akan dikaji dalam penelitian ini adalah apakah terdapat hubungan yang signifikan antara konsep diri dengan prestasi akademik mahasiswa pada mata kuliah teori grup? Adapun tujuan penelitian ini adalah untuk mendeskripsikan hubungan antara konsep diri dengan prestasi akademik mahasiswa pada mata kuliah teori grup. Kontribusi penelitian ini adalah agar para orang tua dan tenaga pendidik dapat membimbing dan memotivasi mahasiswa untuk memiliki konsep diri yang bersifat positif dalam proses pencapaian prestasi akademik yang baik. Penelitian ini juga diharapkan dapat bermanfaat bagi mahasiswa dalam upaya menyadari pentingnya konsep diri dalam pencapaian prestasi akademik mahasiswa pada mata kuliah teori grup.

\section{METODE}

Penelitian ini merupakan penelitian campuran. Metode deskriptif yang dimaksudkan adalah untuk mendeskripsikan hubungan antara dua variabel atau lebih. Penelitian ini merupakan penelitian deskripsi korelasi yang dimaksudkan untuk mendeskripsikan hubungan antara dua variabel atau lebih.

Subjek dalam penelitian ini adalah mahasiswa semester IV kelas E Program Studi pendidikan Matematika FKIP UNSIKA. Jumlah subjek yang akan diteliti adalah 33 mahasiswa. Ruang lingkup dari penelitian ini terbatas pada pendeskripsian hubungan antara konsep diri dengan prestasi akademik pada mata kuliah teori grup dengan materi teori grup terbatas pada fungsi, grup, subgrup, permutasi, grup siklik, koset, homomorfisma, relasi ekuivalen dan isomorfisma.

Instrumen yang digunakan dalam penelitian ini berupa angket konsep diri dan hasil akademik mahasiswa yang diambil dari nilai akhir. Angket konsep diri tersusun dari tiga aspek, yaitu aspek fisik, aspek psikologis dan aspek sosial. Angket konsep diri sebanyak 25 pernyataan dengan menggunakan skala Likert dimana terdapat 4 alternatif pilihan, yaitu Sangat Sesuai (SS), Sesuai (S), Kurang Sesuai (KS) dan Tidak Sesuai (TS). Butir angket dinyatakan dalam dua bentuk, yaitu pernyataan yang bersifat positif dan pernyataan yang bersifat negatif. Prestasi akademik mahasiswa diperoleh dari nilai UAS teori grup. Nilai UAS teori grup didapat dari kehadiran $15 \%$, nilai tugas $15 \%$, nilai UTS 30\% dan nilai UAS $40 \%$. Prestasi akademik mahasiswa tertuang dalam Kartu Hasil Studi (KHS).

Sebelum melakukan pengambilan data penelitian, dilakukan uji coba instrumen penelitian pada 33 mahasiswa. Adapun instrumen penelitian variabel konsep diri dan prestasi akademik mahasiswa pada mata kuliah teori grup yang digunakan untuk di uji coba terlebih dahulu. Dari data hasil uji coba instrumen, akan dilakukan uji validitas dan uji reliabilitas agar mendapatkan instrumen yang valid dan reliabel. Pada penelitian ini perlu dilakukan analisis terhadap data-data yang telah dipe- 
roleh dengan menggunakan teknis analisis korelasi sederhana.

\section{HASIL DAN PEMBAHASAN}

Hasil penelitian ini menyajikan uraian hasil penelitian pada mahasiswa semester IV kelas E Fakultas Keguruan dan Pendidikan Ilmu Pendidikan Universitas Singaperbangsa Karawang tentang hubungan yang signifikan antara konsep diri dengan prestasi akademik mahasiswa pada mata kuliah teori grup.

Melalui analisa data, ingin diketahui jawaban terhadap pertanyaan dalam rumusan masalah. Untuk mencapai tujuan tersebut dilakukan pengolahan data menggunakan bantuan program SPSS dan Microsoft Office Excel. Berikut akan dijelaskan mengenai hasil penelitiannya.

Tabel 1. Hasil Analisis Korelasi Konsep Diri Dengan Prestasi Akademik Mahasiswa

\begin{tabular}{ccccc}
\hline & & Signifikansi & Ket \\
\hline 0,41 & 2,47 & 1,69 & 0,02 & Positif \\
\hline
\end{tabular}

Dari hasil analisis korelasi, diperoleh nilai koefisien korelasi antara konsep diri dengan prestasi akademik mahasiswa pada mata kuliah teori grup sebesar 0,41. Berarti hubungan antara konsep diri dengan prestasi akademik mahasiswa memiliki kriteria kekuatan korelasi yang kuat. Nilai koefisien korelasi adalah positif, maka korelasi atau hubungan antara konsep diri dengan prestasi akademik mahasiswa bersifat searah. Dengan demikian dapat dikatakan bahwa terdapat hubungan positif antara konsep diri dengan prestasi akademik mahasiswa pada mata kuliah teori grup, yang artinya jika semakin baik konsep diri, maka akan diikuti dengan semakin baiknya prestasi akademik mahasiswa. Setelah dilakukan uji t, diperoleh nilai thitung sebesar 2,47 dan nilai Sig. $(0,02)<0,05$, sehingga hubungan kedua variabel ini signifikan. Dengan kata lain terdapat hubungan yang signifikan antara konsep diri dengan prestasi akademik mahasiswa pada mata kuliah teori grup

Hasil analisis di atas menunjukkan bahwa terdapat hubungan yang positif dan signifikan antara konsep diri dengan prestasi akademik mahasiswa. Hal ini sejalan dengan Jalaluddin (2005) yang mengatakan bahwa seseorang dengan konsep diri positif akan terlihat optimis, penuh percaya diri dan cenderung bersikap positif terhadap sesuatu, juga terhadap kegagalan yang dialami. Sebaliknya seseorang dengan konsep diri negatif akan terlihat lebih pesimis, menganggap dirinya tidak berdaya, merasa tidak disenangi, dan tidak diperhatikan. Dengan demikian, mahasiswa dengan konsep diri negatif akan cenderung bersikap pesimistik terhadap kemampuannya pada masalah-masalah matematika dan mudah menyerah dalam menghadapi masalah-masalah matematika. Dengan demikian, konsep diri negatif dapat dimungkinkan berpengaruh buruk terhadap prestasi belajar matematika. Dengan kata lain, dari hasil penelitian yang telah dilakukan, dapat disimpulkan bahwa tinggi rendahnya prestasi akademik mahasiswa berhubungan dengan tinggi rendahnya konsep diri yang dimiliki oleh mahasiswa.

\section{SIMPULAN}

Berdasarkan hasil penelitian yang telah dilaksanakan pada pada mahasiswa semester IV kelas E Fakultas Keguruan dan Pendidikan Ilmu Pendidikan Universitas Singaperbangsa Karawang, maka dapat disimpulkan bahwa terdapat hubungan yang positif dan signifikan antara konsep diri dengan prestasi akademik mahasiswa pada mata kuliah teori grup.

\section{DAFTAR PUSTAKA}

Achdiyat, M., \& Lestari, K. D. (2016). Prestasi Belajar Matematika Ditinjau dari Kepercayaan Diri dan Keaktifan Siswa di Kelas. Formatif: Jurnal Ilmiah Pendidikan MIPA, 6(1).

Ameliah, I. H. (2016). Pengaruh keingintahuan dan rasa percaya diri siswa terhadap hasil belajar matematika kelas VII MTs Negeri I Kota Cirebon. Eduma: Mathematics Education Learning and Teaching, 5(1).

Astuti, E. P. (2010). Identifikasi Kesalahan Menyelesaikan Kalkulus Lanjut Mahasiswa Program Studi Pendidikan Matematika Universitas Muhammadiyah Purworejo. Jurnal Program Studi Pendidikan Matematika Universitas Muhammadiyah Malang, 1(2).

Burns, R. B. (1979). The self concept: in theory, measurement, development and behaviour. London: Longman.

Crocker, J., \& Wolfe, C. T. (2001). Contingencies of selfworth. Psychological review, 108(3), 593.

Firmanto, A. (2010). Hubungan Konsep Diri dan Prestasi Belajar Siswa SMA Shalahuddin Malang. (Doc- 
toral Dissertation) Jurusan Bimbingan dan Konseling \& Psikologi-Fakultas Ilmu Pendidikan UM.

Handayani, F. (2013). Hubungan self efficacy dengan prestasi belajar siswa akselerasi. Character: Jurnal Penelitian Psikologi., 1(2)

Irawati, N., \& Hajat, N. (2012). Hubungan antara harga diri (self esteem) dengan prestasi belajar pada siswa SMKN 48 di Jakarta Timur. Jurnal Ilmiah Econosains, 10(2), 193-210.

Jalaluddin, R. (2005). Psikologi Komunikasi. Bandung: PT Remaja Rosdakarya.

Listiawati, E. (2015). Pemahaman Mahasiswa Calon Guru Pada Konsep Grup. Jurnal APOTEMA, 1(2). 76-86.

Prasetyo, A. (2013). Pengaruh Konsep Diri dan Kedisiplinan Terhadap Prestasi Belajar Siswa Jurusan Teknik Audio Video di SMK Muhammadiyah 3 Yogyakarta. Jurnal, Program Studi Pendidikan Teknik Mekatronika Fakutas Teknik Universitas NegeriYogyakarta.

Purnamasari, M., Isman, J., Damayanti, A., dan Ismaha. (2017). Upaya Meningkatkan Hasil Belajar Matematika Terhadap Konsep Bangun Ruang Materi Luas Dan Volume Balok Dan Kubus Menggunakan Metode Drill Sekolah SMP Islam
Al-Ghazali Kelas VIII. Jurnal Fibonacci: Pendidikan Matematika dan Matematika, 31), 45-52.

Rensi, R., \& Sugiarti, L. R. (2011). Dukungan sosial, konsep diri, dan prestasi belajar siswa SMP Kristen YSKI Semarang. Jurnal Ilmiah Psikologi, 3(2).

Rosmaiyadi. (2018). Analisis Kesalahan Penyelesaian Soal Aljabar Pada Mahasiswa Program Studi Pendidikan Matematika STKIP Singkawang. Journal Pendidikan Matematika, 12(1), 59-70.

Shavelson, R. J., Hubner, J. J., \& Stanton, G. C. (1976). Self-concept: Validation of construct interpretations. Review of educational research, 46(3), 407441.

Slamet, H. W. (2004). Problematika pengajaran kalkulus-1 mahasiswa semester awal. Jurnal Kajian Penelitian Pendidikan Universitas Muhammadiyah Surakarta, 16(1).

Tisngati, U., \& Meifiani, N. I. (2014). Pengaruh kepercayaan diri dan pola asuh orang tua pada mata kuliah teori bilangan terhadap prestasi belajar. Jurnal Derivat: Jurnal Matematika dan Pendidikan Matematika, 1(2), 8-18.

Vandini, I. (2016). Peran kepercayaan diri terhadap prestasi belajar matematika siswa. Formatif: Jurnal Ilmiah Pendidikan MIPA, 5(3). 